\title{
An Analysis of the Adolescent Problems in The Catcher in the Rye
}

\author{
Lingdi Chen \\ Dept. of Foreign Languages, Dezhou University \\ Daxue xi Road, Dezhou 253023, China \\ E-mail: chld1973@126.com
}

\begin{abstract}
The Catcher in the Rye was written by famous American writer J.D.Salinger. This paper mainly analyzes the adolescent problems Holden Caulfield confronts on the journey from childhood to adulthood. These adolescent problems include Holden's protection of innocence, his disgust for the phoniness of the adult world, and his alienation from society. This paper concludes that these adolescent problems produce great impact on him. Holden behaves almost erratically and impulsively and has negative attitudes towards almost everything and everyone he meets.
\end{abstract}

Keywords: Adolescent problems, Innocence, Phoniness, Alienation

\section{Introduction}

The Catcher in the Rye, Salinger's masterpiece, tells the painful story of a high-school boy growing up in the world of decadent New York. Young Holden Caulfield is expelled from school because of his poor academic performance. He is afraid to meet his parents earlier than they should expect him, so he decides to stay in a New York City hotel. There he meets pimps, prostitutes and "queers." Soon he becomes aware that the world of adults is a "phony" one. After his meeting with a friend, Holden sneaks back home to see his kid sister Phoebe. She is a loving kid, but her talk about their father "killing" him sickens him. Creeping out of home, he goes to see his former teacher, Mr. Antolini, only to find that his respectable teacher is a homosexual. And he escapes from Antolini's house. Holden feels himself sinking. Then he decides to go west and spend the rest of his life there. When he goes to say goodbye to his sister Phoebe, she insists on going with him. This unexpected act of love drives him out of his dream and his nightmarish three-day adventure in New York. Finally he goes home, falls ill, and recovers in a psychiatric ward in California. It is there that he recounts his sad story of growing up in The Catcher in the Rye.

Some papers have analyzed the themes of The Catcher in the Rye, the character of the anti-hero-Holden Caulfield, and the use of symbolism and teenage language in the novel. This paper mainly analyses the adolescent problems Holden Caulfield confronts on the journey from childhood to adulthood, those including Holden's protection of innocence, his disgust for the phoniness of the adult world, and his alienation from society.

\section{The adolescent problems Holden confronts}

\subsection{Holden's protection of children's innocence}

Throughout the novel, Holden sees the protection of innocence, especially of children as a primary virtue. It is very closely related to his struggle against growing up. Holden's enemy is the adult world and the cruelty and artificiality. The people he admires all represent or protect innocence. He thinks of Jane Gallagher, for example, not as a maturing young woman but as the girl with whom he used to play checkers. He tells us that he and Jane had no sexual relationship. Quite sweetly, they usually just hold hands. Holden comforts Jane when she is distressed, and it bothers him that Jane may have been subjected to sexual advances from her drunken stepfather or from her date, Holden's roommate, Stradlater.

The red hunting hat, one of the most recognizable symbols from twentieth-century American literature, is inseparable from our image of Holden. It is a symbol of his uniqueness and individuality. The hat is outlandish, and it shows that Holden desires to be different from everyone around him. It is worth noting that the hat's color, red, is the same as that of Allie's and Phoebe's hair. Perhaps Holden associates it with innocence and purity he believes these characters 
represent and wears it as a way to connect to them. He never explicitly comments on the hat's significance other than to mention its unusual appearance.

Holden tells us the symbolic meaning of the museum's displays: they appeal to him because they are frozen and unchanging. He also mentions that he is troubled by the fact that he has changed every time when he returns to them. The museum represents the world Holden wishes he could live in: it's a world of his "catcher in the rye" fantasy, a world where nothing changes, where everything is simple, understandable, and infinite. Holden is terrified by the unpredictable changes of the world - he hates conflict, he is confused by Allie's senseless death, and he fears interaction with other people. Here we can see Holden's struggle against maturity.

The title of the book-The Catcher in the Rye - first appears in Chapter 16, when a kid is singing the Robert Burns song "Comin' Thro' the Rye." In Chapter 22, when Phoebe asks Holden what he wants to do with his life, Holden tells Phoebe that he would like to be a catcher in the rye: he pictures a lot of children playing in a big field of rye around the edge of a cliff. Holden imagines that he would catch them if they start to go over the cliff. His dream of becoming a "catcher in the rye" shows that Holden has affection for childhood. He wishes to save these children from danger so that they may frolic in the fields; we can interpret this as Holden's wish to save the children from the phony adult world. Holden wants to catch children before they fall out of innocence into knowledge of the adult world.

Holden's observations become increasingly random and disjointed, as when he sees profane graffiti in the school. Holden's obsession with the profanity is notable, for it shows his distaste for anything that may corrupt the innocence of children. Holden wishes to shelter children from any adult experiences, revealing his own fear of maturity and his dream of protecting children's innocence, which increase his disgust for and reinforce his resistance to the "phoniness" of the adult world.

\subsection{Holden's disgust for the phoniness of the adult world}

"Phoniness", probably the most famous phrase from The Catcher in the Rye, is one of Holden's favorite concepts. It is a phrase Holden often uses for describing the superficiality, hypocrisy, pretension, and shallowness. He feels surrounded by dishonesty and false pretenses. In Chapter 22, Phoebe tells Holden that she thinks his plan to go to Colorado is foolish, and asks why he fails out of yet another school. He claims that Pencey is full of phonies. He tells her about how everyone except Robert Ackley as a sign of how phony the students are. Holden admits that there were a couple of nice teachers, including Mr. Spencer, but then complains about the Veterans' Day ceremonies.

The criticism toward "phony" things in society is expressed in the novel primarily by the word "phony". Holden is a representative of the world of childhood whose characteristics are the opposite values to those Holden calls "phony". One of the things Holden often calls "phony" is the world of movies and everything about it. Examples of it are his anger toward his brother D.B. because he moved to Hollywood, aversion of Sunny the prostitute who tells him she spends most of her time in film theaters and derision to the three women he met at the bar who are only interested in movies and famous actors. Another thing Holden calls "phony" is the theater. He finds the theater "phony" because he thinks that instead of demonstrating reality as it is, the emphasis is put on polishing theatricality. He says he has never seen so much "phony" things like he sees in the theater. Out of these examples and others we see that for Holden it is very important to be "real", honest and not "phony", thus the criticism toward the "phony" things in society is the most significant aspect of his personality.

Though oversimplified, Holden's observations are not entirely inaccurate. He can be a highly insightful narrator, and he is very aware of superficial behavior in those around him. Throughout the novel he encounters many characters who do seem affected, pretentious, or superficial—Sally Hayes, Carl Luce, Maurice and Sunny, and even Mr. Spencer stand out as examples. Some characters, like Maurice and Sunny, are genuinely harmful. But although Holden spends so much energy searching for phoniness in others, we should point out, he never directly observes his own phoniness. Holden exhibits the same "phoniness" he denounces. For example, at the start of the novel, Ackley asks Holden's privacy and intrusive questions. Later, when Holden's roommate Stradlater is getting ready for a date, Holden follows him into the bathroom, asks Stradlater personal questions, and then tackles him while he is shaving; and his conversation with Mrs. Morrow contains nothing but falsehoods. The only statement that contains any truth is that he is a student at Pencey; otherwise, all of his statements are deliberately misleading. He tells Mrs. Morrow exactly what she wants to hear about her son, and humors her own sense of vanity and self-absorption by making her believe that her son, whom Holden loathes, is one of the most honorable and decent students at Pencey. These lies reveal the complete contempt that Holden holds for Mrs. Morrow and, by extension, all authority figures. He lies in order to mock Mrs. Morrow's sense of delusion while relishing the false view of her son. Holden claims a sense of superiority over Mrs. Morrow, for he believes that he can see clearly Ernest Morrow's personality, while she has a false, idealized portrait of her son. Whatever her delusions, however, Holden treats Mrs. Morrow horribly. He views her either as a target for ridicule or a sexual object, as he flirts with her and even offers to buy her a drink. He takes a trait that demonstrates a typical teenage immaturity, and moves it to an unbearable extreme; his lies become more shameless and outlandish, revealing the disturbing disconnection between Holden's psyche and reality. 
Holden also pretends, lies, and makes irrational and contradictory assumptions. He usually masks his feelings from other people, which alienate him from society. His deceptions are generally pointless and cruel and he notes that he is a compulsive liar. For example, on the train to New York, he makes a mean-spirited and needless joke on Mrs. Morrow. He'd like us to believe that he is a paragon of virtue in a world of phoniness, but that isn't the case. Although he'd like to believe that the world is a simple place, the world is not as simple as he'd like it to be; even he cannot adhere to the same black-and-white standards with which he judges other people. For example, he criticizes Stradlater and others for their snobbery, but Holden reveals himself to be an equal snob, condescending to others because of their cheap suitcases. He believes that the common factor linking people is not intelligence or talent but social class. This establishes Holden's own sense of hypocrisy: although he condemns the behavior of the class to which he belongs, he shares their behaviors and even accepts this value system as reasonable.

Phoniness, for Holden we can say, stands as an emblem of everything that's wrong in the world around him and provides an excuse for him to withdraw into his cynical alienation.

\subsection{Holden's alienation from society}

Throughout the novel, Holden seems to be excluded from and victimized by the world around him. Holden exemplifies typical teenage feelings of alienation. He rejects the idea that life is a game, "Game, my ass. Some game. If you get on the side where all the hotshots are, then it's a game, all right—I'll admit that. But if you get on the other side, where there aren't any hotshots, then what's a game about it? Nothing. No game." ${ }^{\circledR 1}$ He clearly identifies with those on the "other side" of the game, and he feels alone and victimized, as though the world is against him. He feels trapped on "the other side" of life, and he continually attempts to find his way in the world to which he feels he doesn't belong. When he decides to leave Pencey early, his final insult to his fellow students shows that Holden believes himself to be in some major respect different from the other Pencey students. An innate sense of superiority, however unfounded, separates Holden from the other students, for he believes himself to be more honorable and "deep" than the self-centered Stradlater and more refined than the piggish Ackley. Yet Holden demonstrates qualities similar to those of his peers; he suffers from a self-imposed delusion that he is different and chooses to leave Pencey for an uncertain future.

Relationships, intimacy, and sexuality are the problems Holden faces relating to his alienation. Both physical and emotional relationships offer Holden opportunity to break out of his isolated shell. They also represent what he fears most about the adult world: complexity, unpredictability, conflict and change. As he demonstrates at the Museum of Natural History, Holden likes the world to be silent and frozen, predictable and unchanging. As he watches Phoebe sleep, Holden projects his own idealizations of childhood onto her. But in real-world relationships, people talk back, and Phoebe reveals her childhood is different from Holden's romanticized notion. Because people are unpredictable, they challenge Holden and force him to question his senses of self-confidence and self-worth. For certain unspoken reason, seemingly stemming from Allie's death, Holden has trouble dealing with this kind of complexity. As a result, he has isolated himself and fears intimacy. Although he encounters opportunities for both physical and emotional intimacy, he gives up these opportunities them all, wrapping himself in a cynical armor. Even so, Holden still desperately continues searching for new relationships, always undoing himself only at the last moment.

Holden's loneliness, a more concrete manifestation of his alienation problem, is a driving force throughout the book. Most of the novel describes his almost manic quest for companionship as he flits from one meaningless encounter to another. Yet, while his behavior indicates his loneliness, Holden consistently avoids introspection and thus doesn't really know why he always keeps behaving as he does. Because Holden depends on his isolation to preserve his detachment from the world and to maintain a level of self-protection, he often gives up his own attempts to end his loneliness. For example, his conversation with Carl Luce and his date with Sally Hayes are made unbearable by his rude behavior. His calls to Jane Gallagher are aborted for a similar reason: to protect his precious and fragile sense of individuality. Loneliness is the emotional manifestation of the alienation.

As the novel progresses, we begin to perceive that Holden's alienation is his way of protecting himself. Just as he wears his hunting hat to advertise his uniqueness, he uses his isolation as proof that he is better than everyone else around him and therefore above interacting with them. The truth is that interactions with other people usually confuse and overwhelm him, and his cynical sense of superiority serves as a type of self-protection.

We can see that Holden's alienation is the cause of most of his pain. He never expresses his own emotions directly, nor does he attempt to discover the source of his troubles. He desperately needs human contact, care, and love, but his protective wall prevents him from looking for such interaction. Alienation is both the source of Holden's strength and the source of his problems. For example, his loneliness propels him into his date with Sally Hayes, but his need for isolation causes him to insult her and drive her away. Similarly, he longs for the meaningful connection he once had with Jane Gallagher, but he is too frightened to make any real effort to contact her. He depends upon his alienation, but it destroys him. 


\section{The impact of the adolescent problems on Holden}

These adolescent problems Holden confronts exert great influence on him, and results in his erratic behavior, and his negative attitudes towards people, society and everything happening around him we can perceive after reading the novel.

Holden behaves almost erratically and impulsively. There seems to be no rational or reasonable motivation for his behavior. In Chapter6, Holden's inability to control his behavior reaches far beyond any normal teenage impulses. When Stradlater fails to appreciate Holden's composition, Holden suddenly tears it into pieces with great anger. His fight with Stradlater also shows Holden's inability to control himself: when he suspects that Stradlater has slept with his old friend, Holden responds by punching him. In Chapter17, Holden calls Sally Hayes to have a date. During lunch, Holden complaints that he is fed up with everything around him and suggests that they run away together to New England, where they can live in a cabin in the woods. When Sally rejects his idea, Holden calls her a "royal pain in the ass," and she starts to cry. Holden feels somewhat sad, and realizes that he doesn't even know where he gets the idea about going to New England.

Within him, Holden has negative attitudes towards almost everything and everyone he meets. He strongly disgusts the "phony" things in society, especially the theater and the world of movies he often calls "phony". In Chapter17, Holden tells Jane Gallapher that he hates everything: taxicabs, living in New York, phony guys who call the Lunts angels. Holden's unhealthy attitude towards sex deserves our attention. He is disturbed by the fact that he is aroused by kinky, sexual behavior such as spitting in one's partner's face. Although Holden considers such behavior as "crumby", he admits that it is pretty fun, although he doesn't think that it should be. Holden even appreciates sexuality in its most lurid forms, relishing Carl's gossip about which actors are closeted homosexuals, and can only conceive of Carl's relationship with the sculptress in terms of exotic sensuality. Holden harbors disgust for his teachers except Mr. Spencer and Mr. Antolini and dislikes his roommates Ackley and Stradlater. Ackley is rude: "He always picked up your personal stuff and looked at it."2 and in appearance he is very disgusting:"I never even once saw him brush his teeth. They always looked mossy and awful...Besides that, he had a lot of pimples...all over his whole face." ${ }^{\text {, Stradlater is }}$ outwardly handsome and charming but "Stradlater was more of a secret slob."(4)

\section{Conclusion}

Adolescence is one of the momentous, beautiful, yet turbulent eras in one's life. It is here when people experience conflicts inside their psyches, ambivalence towards themselves, towards the people around them, and towards society. It is here when people begin to grow up. Without exception, it is the same with Holden Caulfield.

Holden represents a social type of adolescents growing up in a corrupt and decadent world and serves a mirror for his peers. There is a lot in him with which the young can identify. Much of Holden's candid outlook on life, on people around him, on society is still relevant to the youth of today and contains a truth of an eternal nature.

This paper concludes that these adolescent problems Holden confronts exert great influence on him, and results in his erratic behavior, and his negative attitudes towards people, society and everything happening around him. From these adolescent problems Holden meets, we learn that both parents and people in society should care and love one another, especially children, that we should help the young adapt them to the changing society, and that we should help the young establish healthy outlook on world and life. Thus the young can grow up in a sound way.

\section{References}

Alexander, Paul. (1999). Salinger, a Biography. Los Angeles: Renaissance Books.

Bloom, Harold. (1990). Holden Caulfield. New York: Chelsea House Publishers.

Engel, Steven. (1998). Readings on The Catcher In The Rye. San Diego: Greenhaven Press.

Grunwald, Henry. (1962). Salinger: A Critical and Personal Portrait. New York: Harper.

Hamilton, Ian. (1988). In Search of J.D.Salinger. New York: Random House. 